\title{
The Perceptions of Primary School Teachers of Online Learning during the COVID-19 Pandemic Period: A Case Study in Indonesia
}

\author{
Rasmitadila ${ }^{1}$ \\ Universitas Djuanda, Jawa Barat, Indonesia \\ Rusi Rusmiati Aliyyah \\ Universitas Djuanda, Jawa Barat, Indonesia \\ Reza Rachmadtullah \\ Universitas PGRI Adi Buana, Jawa Timur, Indonesia \\ Achmad Samsudin \\ Universitas Pendidikan Indonesia, Jawa Barat, Indonesia \\ Ernawulan Syaodih \\ Universitas Pendidikan Indonesia, Jawa Barat, Indonesia \\ Muhammad Nurtanto \\ Universitas Sultan Ageng Tirtayasa, Banten, Indonesia \\ Anna Riana Suryanti Tambunan \\ Universitas Negeri Medan, Medan, Indonesia
}

\begin{abstract}
This study explores the perceptions of primary school teachers of online learning in a program developed in Indonesia called School from Home during the COVID-19 Pandemic. Data were collected through surveys and semi-structured interviews with 67 class teachers in primary schools. Data analysis used thematic analysis of qualitative data. The analysis results found four main themes, namely, instructional strategies, challenges, support, and motivation of teachers. This research contributes to the literature of online collaborative learning between teachers, parents, and schools that impact student success. Broadly, the success of online learning in Indonesia during the COVID-19 Pandemic was determined by the readiness of technology in line with the national humanist curriculum, support and collaboration from all stakeholders, including government, schools, teachers, parents and the community.

Keywords: COVID-19, Indonesia, online learning, primary school, school from home.
\end{abstract}

\section{Introduction}

The outbreak of COVID-19 Pandemic across the world has profoundly altered almost all aspects of life, including education, and Indonesia has not been an exception to these changes. The

${ }^{1}$ Correspondent Author E-Mail: rasmitadila@unida.ac.id 
difficulty of handling the outbreak from spreading more widely has made world leaders develop super-strict rules so that the chain of the spread of COVID-19 can be broken. Some standards that the World Health Organization (2019) has recommended, such as social distancing and physical distancing, have created difficult choices for each country to implement. In Indonesia, "large-scale social restrictions" were adopted in March 2020 due to the increasing number of people infected with COVID-19. These were followed by other regulations in the form of working from home for workers, praying from home, and homeschooling for students ranging from the early childhood education level to higher education (Regulation of Indonesian Government No.21, 2020, 2020). According to the United Nations Educational, Scientific and Cultural Organization (2020), as many as 1,186,127,211 learners were affected across the globe, or about $67.7 \%$ of the total enrolled learners from 144 country-wide closures, and nations had to change their learning systems due to COVID-19.

Changes in learning systems force schools to implement distance education or online learning, e-learning, distance education, correspondence education, external studies, flexible learning, and massive open online courses (MOOCs). The same conditions and rules apply in the United States. According to the Centers for Desease Control and Prevention (2020), e-learning plans have been implemented, including digital and distance learning options, as feasible and appropriate to ensure the continuity of education for students during the COVID-19 pandemic. A report from The World Bank (2020) stated that several countries had implemented different learning systems as physical schools were closed due to COVID-19. For example, in early February 2020, China implemented an online learning system by holding simultaneous online learning exercises to ensure that learning for students was not interrupted. In Bulgaria, in early April 2020, the Ministry of Education and Science launched an e-learning system. In Finland, on account of school closures, instruction and guidance for students have been implemented by distance learning, digital learning environments and solutions and, where necessary, independent learning. Several ways to support e-learning have been found that including creating an e-Content Repository, which publishes materials of pedagogical specialists for working in e-learning environments.

The Indonesian government's implementation of large-scale social restrictions has impacted the routines of the community and students in the learning system. Distance learning or using online systems have provided solutions for schools that are starting to implement the School from Home (SFH) system. SFH is a program that migrates the learning process from school to home. Based on the instructions of the Ministry of Education and Culture, schools are to organize online learning to provide a meaningful learning experience for students without being burdened with the demands of achieving all curriculum requirements. In this, SFH considers the health and safety of students, educators, education staff, and the community.

Online learning emphasizes Internet-based courses offered synchronously and asynchronously. Synchronous learning is a form of learning with direct interactions between students and teachers while simultaneously using online forms such as conferences and online chat. Meanwhile, asynchronous learning is a form of learning indirectly (not at the same time) using an independent learning approach. Some subject matter is designed and displayed on LMS on Moodle, or email systems, blogs, online discussions, Wikipedia, videos, articles, and other platforms (Ko \& Rossen, 2017; Ogbonna et al., 2019; Papachristos et al., 2010; Sturm \& Quaynor, 2020; Tarman, 2020). Students have access to the teacher synchronously, asynchronously, or both (Hunter \& St. Pierre, 2016; Inoue, 2007; Ohlin, 2019; Richardson et al., 2020).

During the SFH implementation period (March to early June 2020), stakeholders faced many obstacles, especially schools that suddenly had to apply SFH. The application of SFH has presented challenges in implementing online learning systems, especially in the use of facilities 
and the availability of infrastructure, which has been minimal so far. Additionally, the transition of instructional methods that traditionally have been through face-to-face to more indirect methods has forced schools to engage in a learning flow that has complexities and limitations.

Various problems have included the provision of school infrastructure (Bakalar, 2018), such as an Internet network that all schools have not enjoyed previously, especially in villages, as well as the cost of purchasing expensive data packages. Although the Indonesian government recently issued a regulation that school operational funds could be allocated to buy data packages, schools still could not fully enjoy SFH learning. In addition to data packages, bad signals are obstacles in the implementation of learning. Often students are late in collecting and completing assignments, and even understanding the material has become a significant problem for students. Another change is that the involvement of parents with children has become more intense in SFH than in pre-SFH learning. Parents can assist children in understanding subject matter that is not understood or conveyed well by a teacher. Collaboration between teachers and parents in elementary schools is necessary for the implementation of online learning because parent mostly own support hardware such as cellular phones or laptops.

Teachers, as the spearhead of the implementation of online learning, must be able to condition all instructional components. These include instructional methods, media that will be used in learning, use of instructional time related to the time of application use, and psychological and social factors that significantly affect teachers' motivation when teaching. Teachers have tasks and responsibilities that are not easily transferrable when they must change from the face-to-face learning system in the classroom to an online system coupled with online learning experiences that have never been implemented before. A teacher must overcome all the problems that occur in online learning responsively so that the learning continues to achieve the targets set.

This study explores the perceptions of primary school teachers of online learning as an impact of school from home during the COVID-19 Pandemic in Indonesia.

\section{Methodology}

\section{Research Design}

The research used a case study. The purpose of the case study is to allow researchers to obtain and examine data in a context or phenomenon. The selected cases can be people, students, or staff schools who are members of a school community (Creswell, 2011). Case study data is used to describe a case in-depth in real-life comprehensively (Yin, 2012). In this study, the impact of online learning as an impact of SFH on primary classroom teachers was explored in-depth during the COVID-19 Pandemic in Indonesia.

A literature search was carried out to determine the conceptual and operational definitions of the research focus, namely data relating to online learning during the COVID-19 Pandemic. The creation of the instruments for data collection was based on operational definitions, and the instruction was divided into three main parts that included instruction, psychological and social issues. Data collections were done in stages, through online surveys and then semi-structured interviews to obtain in-depth data. Data analysis was conducted following established procedures for analyzing observation items and indicators (Braun \& Clarke, 2006). 


\section{Participants}

Participants in this study were 67 class teachers in primary schools in 5 provinces, namely, Jakarta, West Java, East Java, Central Java, and West Kalimantan, Indonesia. A purposive sampling technique was used by distributing questionnaires online using Google Form to representatives of research colleagues who had access to primary schools in the five provinces. The selection of the five provinces was based on COVID-19 distribution data obtained from the Indonesian COVID-19 Task Force as a special body handling the COVID-19 Pandemic in Indonesia. Descriptive data of demographic characteristics, including gender, length of teaching experience, and level of education of the teachers, are presented in Table 1.

\section{Table 1}

Profile of Participants

\begin{tabular}{lcc}
\hline & Frequency & $\%$ \\
\hline Gender & & \\
Female & 60 & 89.6 \\
Male & 7 & 10.4 \\
Working years as a teacher & & \\
$1-5$ years & 18 & 26.9 \\
5 -10 years & 22 & 32.8 \\
$10-15$ years & 16 & 23.9 \\
$15-20$ years & 6 & 9.0 \\
20 years & 5 & 7.5 \\
Level of education & & \\
Bachelor's & 49 & 73.1 \\
Master's & 10 & 14.9 \\
Others & 8 & 11.9 \\
\hline
\end{tabular}

\section{Data Collection}

Data collection was conducted in two stages. The first step was carried out using a survey of classroom teachers in primary schools in five provinces in Indonesia who used online learning during SFH as respondents. The survey comprised 10 questions in the form of short answers, using Google Form. The questions were arranged based on the literature relevant to the purpose of the research, which covers the instruction, psychological and social aspects of the classroom teacher. The survey data were collected from May 15, 2020, to May 23, 2020, and 67 respondents participated. After the survey data were collected, a transcript of the results of each respondent was made, and initial codes were created. The second stage of the collection was conducted using semistructured open-ended questions with 10 of the 67 elementary school teachers who responded to the survey. Researchers made interview guides based on the initial code from first stage data. The purpose of the interviews was to get more meaningful data. Interviews were conducted online for 1.5 - 2 hours per respondent via the WhatsApp application from May 26, 2020, to May 29, 2020. Every day researchers interviewed 3-4 respondents. Each teacher was assured of confidentiality and assigned a pseudonym. 


\section{Data Analysis}

Data were analyzed using inductive and thematic analytics to identify, evaluate, and make a theme expressed by participants (Galloway \& Jenkins, 2005). The responses of each participant, especially in the first stage, were coded using keywords so as not to overlap. The NVivo 12 program was used to facilitate the coding and categorization of researchers. Data from surveys and interviews were entered into Nodes and Cases to be grouped into data with specific codes. Thematic maps show the organization of concepts according to various levels, and potential interactions between concepts were then developed. The analysis team then discussed all codes and categorizations, as well as the possibility of integration between codes so that the codes could be streamlined. This inductive technique allowed the identification of themes that participants gave in response to the research questions (Liu, 2011). See Figure 1 below.

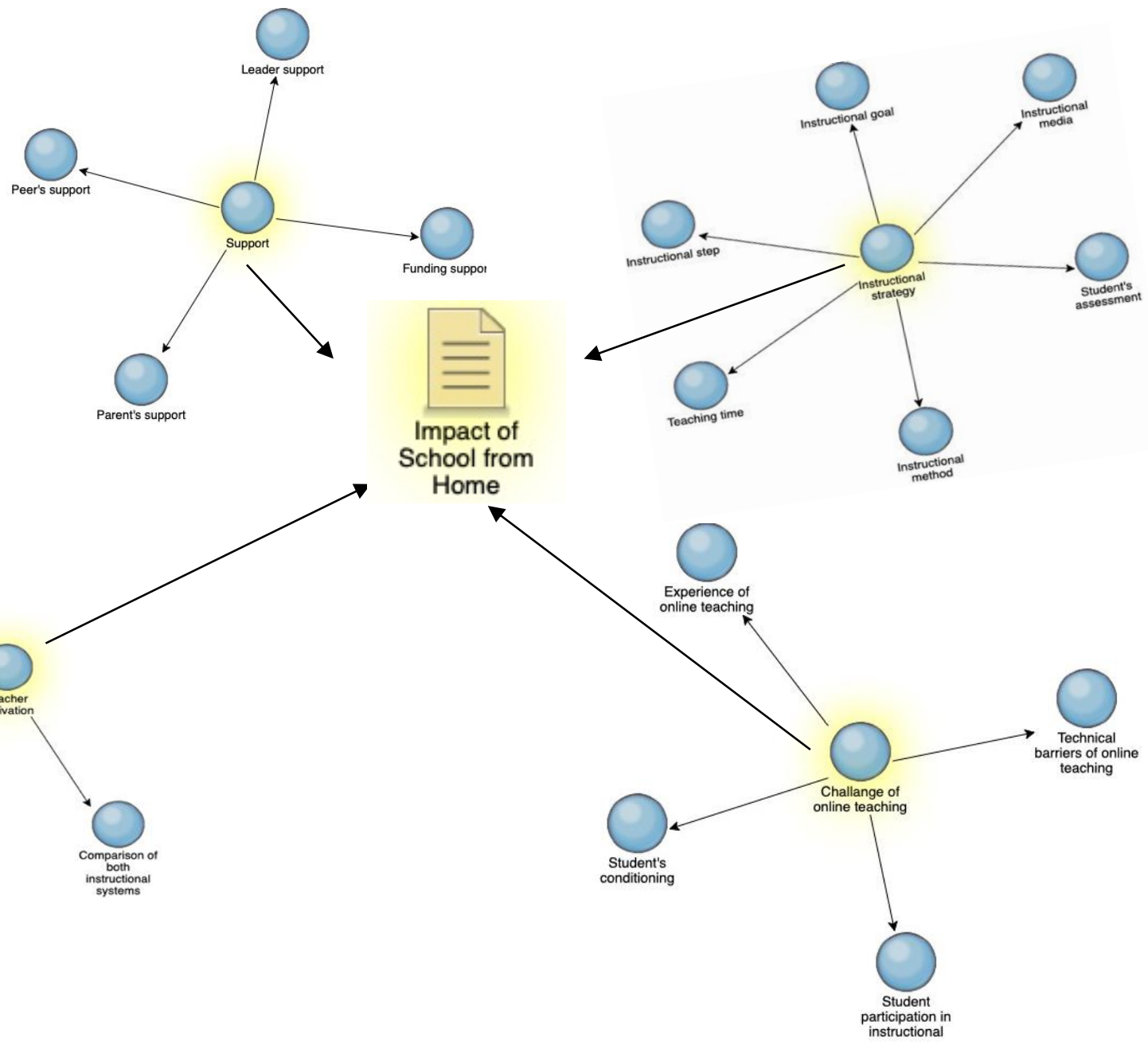

Figure 1. Results of Data Analysis of Classroom Teacher Perceptions of the Impact of SFH During the COVID-19 Pandemic

Credibility and dependability were considered during this research. Starting from data collection instruments were used based on a review of relevant literature. This instrument was also designed using expert opinions for e-learning experts, experts in social studies, as well as experts 
in educational psychology. After the data were collected, member-checking (Lincoln et al., 1985) was used to check credibility, in which participants (especially in interviews with 10 class teachers) were asked to clarify that their contributions were accurately reflected in previous data. The use of investigator triangulation involving all seven researchers in all stages of research with regular conferences added to dependency (Patton, 2014). Triangulation of investigators also helps researchers to reduce bias because triangulation facilitates the cross-checking of the integrity of participant responses (Anney, 2014). Furthermore, the involvement of seven researchers to investigate the same problem brought different points of view to the investigation, thus, supporting the integrity of the findings.

\section{Findings}

\section{Instructional Strategy}

Instructional strategies are a set of instructional components used in instructional activities to achieve instructional objectives (Dick, 2013; Baturay, 2008). The instructional strategies found in this study included objectives, learning steps, methods, media, time, and learning assessments. See Figure 2.

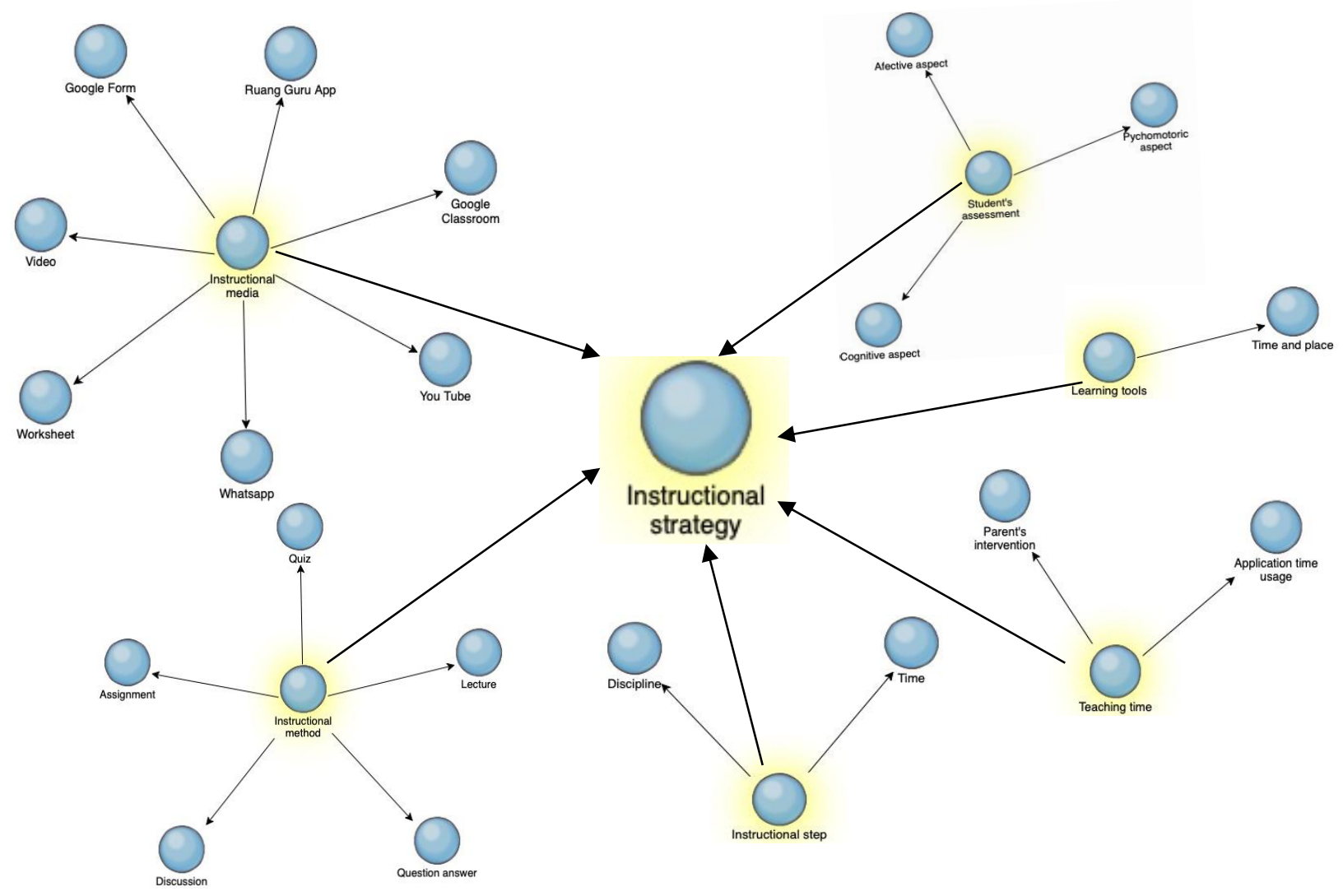

Figure 2. The Instructional Strategy on Online Learning Used by Teachers in SFH

The use of instructional media aims to make it easier for students to understand the subject matter (Abdo \& Semela, 2010; Kadzera, 2006) by providing a different learning experiences that 
are expected to stimulate the interest of students and their motivation to learn (Aini, 2013; Arsyad, 2014; Dinh, 2019). The instructional media that teachers most often used were learning videos, which were either downloaded from YouTube and or learning videos that teachers had created before the COVID-19 Pandemic. Some teachers said that instructional videos were one of the most accessible media to use because the teacher already had time, and students could easily understand the subject matter. Several class teachers shared this opinion:

I use videos that I have downloaded from YouTube and some videos that I had before COVID-19 so that students more easily understand the subject matter. (Teacher 6)

I find it challenging to use other instructional media besides videos because pandemic conditions limit me [from being] more creative in making other media. (Teacher 12)

Besides video, WhatsApp, Google Forms, Worksheets, YouTube, and Zoom also served as media in delivering learning material. Teachers sent lesson material using WhatsApp, Google Forms, and Worksheets to students' parents, which was subsequently given to the students. The use of this instructional media was related to the media that most parents also use.

The most commonly used instructional methods were the question and answer (Q\&A) format (Cao et al., 2010) and lectures. The use of the Q\&A method was the easiest way for teachers to measure students' understanding of the subject matter being taught and the discussion method that allows for two-way interaction between teachers and students. Teachers carried out the Q\&A method and discussion using Zoom, Google Classroom, and PowToon. Teachers also used the lecture method due to time constraints and other problems such as poor Internet signals, and the condition of virtual classrooms that are less conducive to learning. SFH forces teachers to use quick and easy instructional methods. Teachers used alternatives such as offline assignments and quizzes with a predetermined time limit to determine the level of student understanding. Of this, teacher 10 said,

I have difficulty using instructional methods that are more attractive to students like in the classroom because the conditions are not possible. Everything is limited, including quota availability, sometimes bad signals, and students are not ready. So, I use the question and answer method to find out whether students are familiar with the material that I submit. (Teacher 10)

In SFH, teachers must be able to use limited time, which automatically influences the pace of learning, instructional objectives, and learning assessment. The instructional time that teachers usually used in one meeting before SFH was 1.5-2 hours, but during SFH, the time was shorter because of the intervention of parents, as well as the limited use of application time. When students work on assignments or do questions and answers with the teacher, parents help them by giving answers so they can quickly answer questions. So, the use of online applications causes teachers to convey only important points of subject matter that must be delivered to students. The use of the instructional time that changes in each meeting also affects the instructional steps, including the discipline of students in the following learning. Discipline involves turning in assignments on time and not delaying the completion of the task at hand, so students must study the materials to not 
experience delays in instructional time. Of course, the availability of learning facilities such as mobile phones/laptops and Internet data quotas from parents is crucial in the implementation of learning. Changes in instructional objectives and steps will also automatically affect the way and forms of learning assessment for students.

A teacher cannot fairly conduct assessments, which include cognitive, affective, and psychomotor aspects in an online environment. Indeed, teachers often felt that proper assessment of the cognitive aspect was challenging to do fairly because of the intervention of parents who helped provide answers to the assignments/tests given by a teacher. Assessment of psychomotor aspects is often better. Assignments such as singing or practicing specific movements can be assessed better by a teacher because these are based on student abilities without parental intervention when recording.

Meanwhile, teachers also find it challenging to judge affective aspects that refer to students' attitudes because of differences in attitudes shown at school and home. This condition tends to be due to parental intervention that does not reflect the actual circumstances of students, which might be seen in school before SFH. Teacher's perceptions of the impact of learning time, goals, steps, and student assessment can be seen in the opinions of two teachers.

The instructional time during SFH tends to be shorter, because of the limited time I use applications such as Zoom so that my learning steps are adjusted to the existing conditions. Besides, I also change instructional objectives by reducing the amount of material, as well as fewer goals from face-to-face. (Teacher 11)

I find it difficult to assess cognitive aspects because of the intervention of parents to provide answers to their children, so the assessment is not fair enough to describe the understanding of students. (Teacher 21)

Instructional strategies implemented by teachers during SFH have had impacts that have degraded the quality of learning. Changes in instructional time lead to changes in instructional objectives, instructional steps, instructional methods, media, and students' assessment. The involvement of all members of the school community in the quality of learning during the SFH period lies not only in the role of the teacher. Parents are also involved in providing support for their children's progress, acting as providers of learning facilities, and providing opportunities for children to obtain competencies. A teacher must be creative and innovative in designing methods of instruction so that learning objectives can be achieved.

\section{The Challenge to Online Teaching}

The challenges that teachers face in an online environment during SFH include four subthemes, namely, technical obstacles, student conditioning, the participation of students, and online teaching experience. Figure 3 below illustrates the challenges that teachers face.

Teachers faced several challenges related to the emergence of obstacles associated with technical issues. Not all parents have cell phones/laptops, and Internet signals are poor, especially in the suburbs. The challenges that these obstacles present determine the instructional activities that can take place. Problems can arise if these technical obstacles cannot be overcome and mean that student participation in learning is not optimal. As a result, some students cannot follow the lessons and experience delays in completing an assignment that the teacher gives. These technical 
obstacles often occur for students with a low economic level. This condition is explained by the teachers below:

Difficulties in setting up online systems that are too complex or because of poor networks. Some students don't have cell phones or laptops. (Teacher 16)

My difficulty in online learning is that to be able to take part in students' lessons, it requires a lot of quota, and signals are good, let alone a lot of material that must be delivered. (Teacher 4)

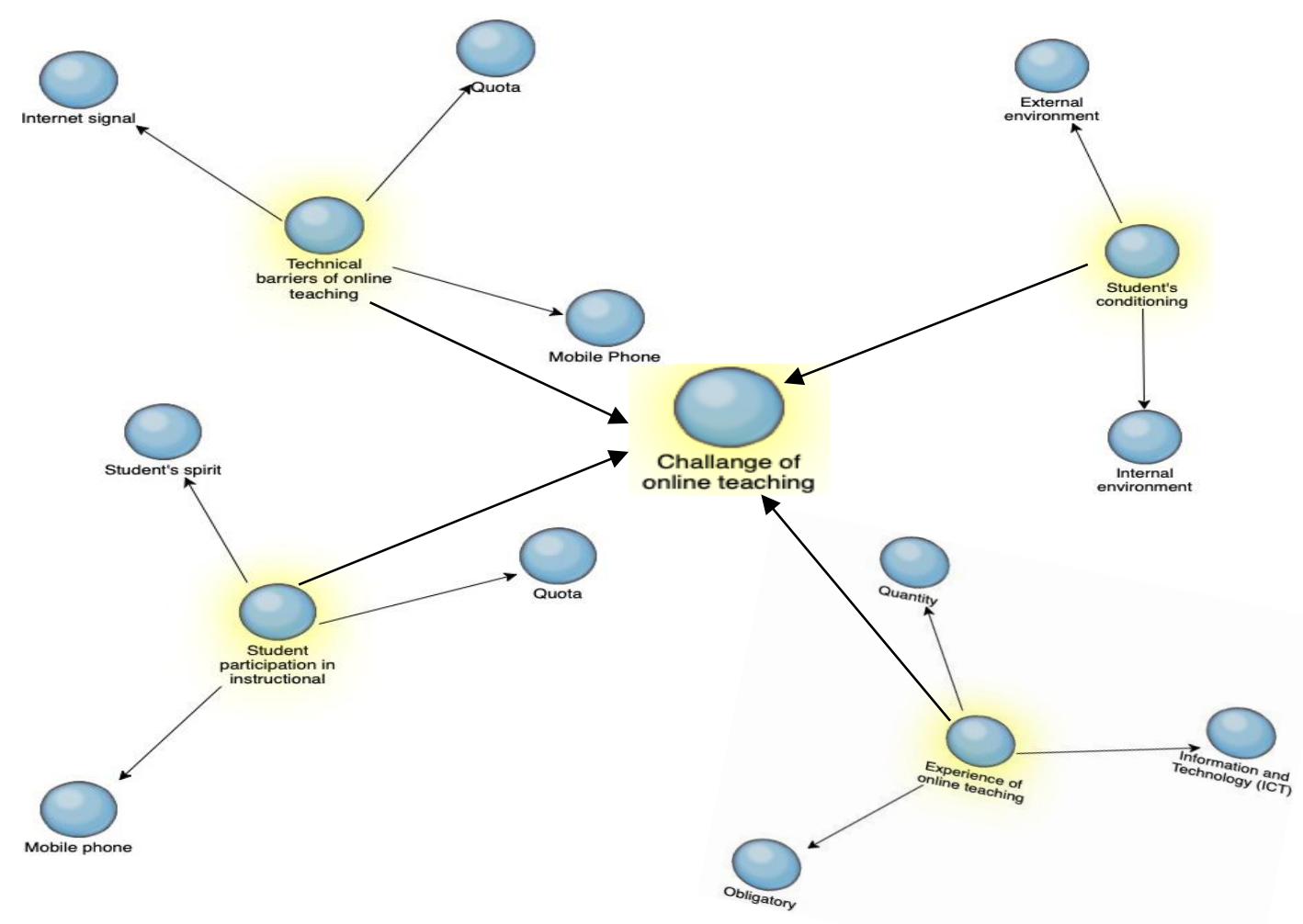

Figure 3. Teachers' Challenges in Teaching Online During SFH

In the implementation of online learning during SFH, the availability of data packages and Internet networks, and ownership of cellular phones or laptops is an absolute must. Students must have these so that all instructional activities can be followed smoothly. Although some teachers end up doing offline learning or visiting students at home because of these factors, the risk of spreading COVID-19 is significant, so teachers rarely do these. A teacher must be able to consider extending the completion time so that the needs of all students can be accommodated. Through the Ministry of Education and Culture, the Government of Indonesia has helped in the form of school operational assistance funds; the expectation is that this support will boost the sustainability of learning related to technical obstacles that can be overcome properly. 
Other challenges, such as conditioning students to participate in online learning, is difficult for teachers. Factors that create these barriers may be divided into internal and external factors. Internal factors are difficulties arising from the student's home environment, such as interference from family members (younger and older siblings). These factors cause students who are learning not to be focused on learning. One factor is a less conducive home learning environment in which the activities of family members students cause distractions that reduce the concentration necessary to understand the subject matter. External factors that arise are the disturbances from other students when implementing learning using an online application in a virtual classroom. Students talk to other students with topics that are unrelated to the subject matter being studied. As a result, virtual classes become crowded and less conducive. Teachers 8 and 34 remarked on this.

When lessons are taking place, sometimes the situation of the student's home is less conducive, for example, interference from younger siblings or students who are disturbing). (Teacher 8)

I have to reprimand students often because they sometimes talk when learning takes place, which reduces learning time, and I cannot measure student understanding. (Teacher 34)

Conditioning students by teachers remains difficult during SFH, and a teacher must carry out conditioning activities in the virtual classroom so that learning can run smoothly. This dramatically determines the enthusiasm and motivation of students to learn. For this reason, a teacher must be able to ensure that all students are ready to learn and look for creative ways to engage them.

Another challenge that is closely related to student conditioning is the participation/activeness of students in learning activities. Student participation in instructional activities is faced with problems of data packages and ownership of cellular phones or laptops, as well as the enthusiasm of students to learn. Like the conditioning of students, the teacher must also seek ways to maintain student enthusiasm. During SFH, several teachers stated that it was not easy to maintain student enthusiasm for learning. At the beginning of SFH and online learning, students were enthusiastic about implementing learning, but after two months, students began to feel bored and less eager to learn. Teachers 1 and 17 explained this.

If the beginning of SFH, students are still enthusiastic, but after two months, students often feel bored. (Teacher 1)

I try to make students not get bored using online learning because I see after 1-month students feel bored, and some complain that they want to study in class as usual. (Teacher 17)

The technological experience of teachers in an online environment is also one of the challenges that determines the smoothness of instructional activities (Conrad \& Donaldson, 2011; Ko \& Rossen, 2017; Watson, 2020). The emphasis on the duties and obligations of teachers in teaching during SFH, and the ability of teachers to understand ICT have impacted the success of online learning during SFH. Teachers who do not have online teaching experience or have difficulty running technology and information tools will usually find it challenging to carry out online learning because SFH forces teachers to master a variety of applications. Even teachers who 
have teaching experience or senior teachers can find it difficult to run applications. This condition becomes a burden for teachers in implementing instruction, so learning is not optimal. For teachers who master applications, technology tools, and computers, online learning can be an effective instructional method to use during SFH. Teachers 22 and 14 talked about this condition:

So far, I have never taught online, but because I have to learn online, I find it challenging to implement it because I lack knowledge of technology. (Teacher 22)

Sometimes it becomes a burden for me when I cannot teach online because I have never taught online. (Teacher 14)

The challenges that teachers faced impacted students learning. All technical barriers, conditioning, and student involvement, and online teacher teaching experience negatively impacted the achievement of instructional objectives and high-quality learning

\section{Support}

Instruction during SFH will not run smoothly if support from colleagues, headmasters, and schools is not provided. Without proper support, a teacher who must design instruction might lose confidence and enthusiasm. Implementing online learning has changed instructional strategy, so support from colleagues, parents, headmasters, and schools is vital to continue the implementation of instruction in an orderly manner.



Figure 4. Support for Teachers in Online Learning During SFH

Support from peers includes encouragement to continue teaching online, helping each other if there are fellow teachers who cannot use other computer applications or programs, as well as coordination of classroom material between classes conducted online. Teachers 10 and 32 made the following comments. 
[We must be] very supportive and motivating to one another because if a teacher does not have the motivation to teach how students will learn. (Teacher 10)

Peers encourage one another, that teaching is not a burden, even though it has to teach with an online system. (Teacher 32)

Support from parents contributes quite significantly. Parents feel that online learning has changed the quality of their children's learning. At the beginning of online learning, parents were very enthusiastic that the school was using an online learning system. After more than a month, parental support decreased. The low Internet literacy of some parents is an issue, as is the largescale social restrictions program that has caused many offices to lay off employees, causing economic problems. For families whose parents have lost their jobs, loss of income has meant the reduction of expenses like Internet services. Some students do not have cell phones or laptops that are commonly used in interacting with teachers in virtual classrooms. Below are the comments of teachers 11 and 32.

Not all students and parents are Internet literate. (Teacher 11)

To do online, it needs support from various factors; one of them is economic. (Teacher 32)

Headmasters play an essential role in determining and implementing policies that are appropriate during SFH. Support from headmasters in SFH conditions can be in the form of motivation to teachers, coordinating all school equipment, teacher readiness, funding, and other supporting aspects such as the availability of learning facilities and infrastructure. Motivation or enthusiasm from the headmaster provides comfort to a teacher so that learning can take place smoothly (Whitaker et al., 2013). The headmaster determines the funds to support online instructional activities such as data packages, which are essential for implementing online learning. School funds allocated to support all school activities during the SFH, guided by the Ministry of Education regulations, provide the flexibility for school principals to determine the appropriate allocation of funds, which may be may be made to the operational funds of teachers and the school as a whole. Teachers 16 and 33 commented on this.

I think headmasters and colleagues motivate each other for instructional activities during the COVID-19 Pandemic; the reason is that we all support each other for mutual progress and help each other if we have difficulties. (Teacher 16)

Headmasters and peers motivate each other to teach during the COVID-19 Pandemic, including funds for the purchase of pulses and internet quota. (Teacher 33)

So, the support of headmasters and schools helps to determine the implementation of online learning during SFH. Headmasters must ensure that all teachers can carry out instructions with enthusiasm so that all students can learn despite physical distancing and social distancing during the COVID-19 Pandemic. 


\section{Teacher Motivation}

The implementation of SFH has experienced ups and downs in teacher motivation related to conditions that changed during the COVID-19 Pandemic. Changes in the environment with an increase in the number of people affected by the COVID-19 virus have altered not only lifestyles but also the enthusiasm to carry out work-related activities. High motivation is essential for teachers to have during the SFH because the complexity of instruction requires teachers to overcome problems in virtual classrooms quickly. Three things have influenced teacher motivation during SFH: a teacher's spirit in carrying out online learning, a teacher's enthusiasm, and the duties and obligations of a teacher. These three things are interconnected and determine the success of learning being carried out with students.

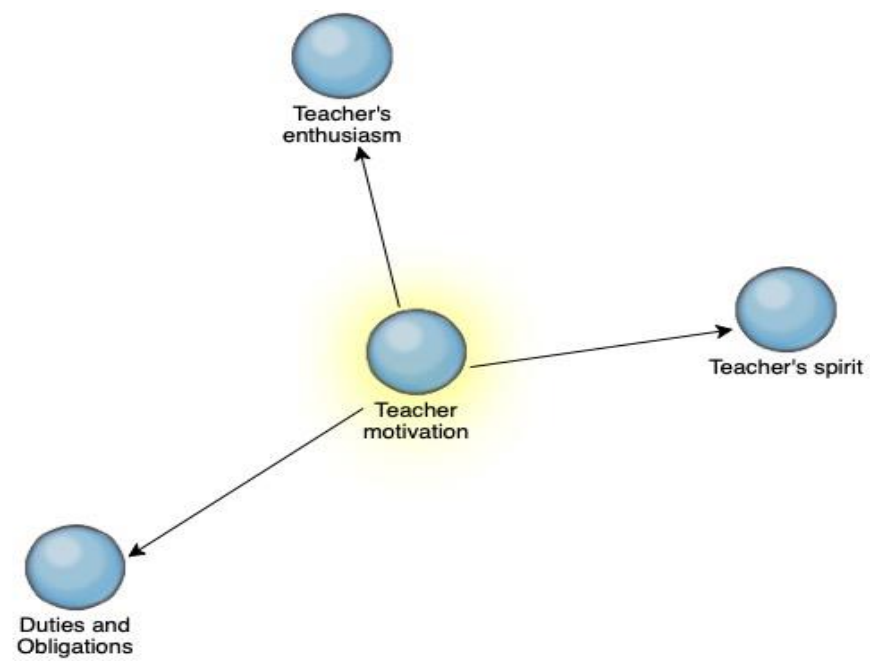

Figure 5. Teacher Motivation to Teach Online Learning During SFH

Teaching motivation during the SFH period must be kept stable because of the dynamic learning environment due to the COVID-19 Pandemic. Teacher enthusiasm is directed at achieving high teacher performance (Patrick et al., 2000). However, teachers are less enthusiastic with SFH than with face-to-face learning. Teachers cannot interact directly (face-to-face) physically with students, so teachers cannot gauge the understanding of students when learning online. This lack of physical interaction, in turn, has led to a decline in the enthusiasm to teach (Hennessy et al., 2005; Ruthven et al., 2004; Strunc, 2020). Teacher 27 said:

I am more enthusiastic about teaching face to face because I can interact directly with children, share their joy with them, and carry out the learning process more optimally. (Teacher 27)

Teacher 18 added:

[I am] Less enthusiastic because I cannot teach directly. (Teacher 18)

Thus, after three months of conducting SFH, the spirit and enthusiasm of teachers had decreased, causing teachers to go through the motions to complete teaching obligations until the end of the semester. 


\section{Discussion}

School from home during the COVID-19 Pandemic has significantly impacted all countries in the world. Within a few months after the COVID-19 Pandemic began, almost all countries ad implemented online learning systems, both online (using online applications, TV, radio) and offline (printed books, modules). In Indonesia, changes in the instructional system during the SFH period because of the COVID-19 Pandemic have impacted learning activities for teachers, students, and parents (Cheng, 2020). These included impacts on instructional strategies and techniques. In the context of Indonesia, these included changes in instructional strategies, technology readiness to teachers in implementing online learning, support, and the motivation of teachers, parents, schools, and government involvement. Thus, SFH must be well established so that learning objectives can be achieved (Guo \& Li, 2020; Kaup et al., 2020).

The impact of the changes in the teaching and learning process brought about by SFH has affected teacher performance and the quality of education, especially in Indonesia. In this current study, the participating teachers believed that instructional strategy needed change and that all stakeholders, including governments, schools, social organizations, school committees, parents must sit together to determine and formulate online learning goals that are in line with a national curriculum based on humanism. Concerning instructional strategies, they stressed that technological readiness including technology capacity, whether online use (TV learning, radio, online applications) or offline (printed teaching materials, modules, textbooks) was necessary to support the success of online learning

Another aspect is teaching material adapted to the conditions and needs of students (Rachmadtullah et al., 2020; Rasmitadila et al., 2020). The development of these materials requires time, effort and focus from a teacher because the teaching of the subject matter before SFH and using SFH is radically different. A teacher must align the instructional objectives with the context of teaching in a new learning environment (Yao et al., 2020). Parents must understand the material because parents help students to understand the subject matter in the SFH process. The situation becomes even more complicated if parents do not understand the subject matter, and the instructional process does not go according to the instructional strategies that a teacher has set. Teachers can modify instruction using a pedagogical approach that suits their interests and abilities cognitive, including using group discussion methods, peer assistance, and peer assessment (Guo \& Li, 2020; Khairuddin et al., 2019; Soltero Lopez \& Lopez, 2020; Zhao et al., 2020). The emphasis of instruction should be more on how well students understand a lesson, without being burdened by the national curriculum before SFH.

Student involvement and participation in online learning must be boosted because they seem to have lost interest over time. The use of varied instructional methods will encourage more enthusiastic participation in online learning. In this respect, the government should develop online educational resources that align with the national curriculum and help teachers in the process. (Vlachopoulos, 2020). Such free materials would reduce the burdens on the teacher to create learning materials and reduce costs to parents and students. Besides online educational resources, video conferencing applications, media applications, social media or other social features can help parents cope with the availability of student teaching materials at home (Dutta, 2020; Lemay \& Doleck, 2020). To help address this issue, the Indonesian government created an Education TV program called "learning from home" through the government TV network (TVRI) to help children learn from home for school level from education early childhood to secondary school.

Unfortunately, many of these methods require money for hardware and software

applications and for expanded data plans to use the materials. Lack of money to acquire these 
resources remains an issue in Indonesia. Indeed, according to Sikirit (2020), the most significant obstacle that students face when studying at home is the lack of Internet access and electronic devices.

The support of parents, teachers, and government (central and regional) is urgently needed in the SFH process (Guner, 2019Karataş \& Oral, 2015). This support has several elements. One is the continuous support for the training of teachers in using technology and designing and monitoring online learning (Alrefaie et al., 2020). A second necessary source of support is the involvement of parents, teachers, and the school is a collaborative effort, which can be achieved by creating a community of knowledge to understand online learning practices. Learning materials developed by this community can be created collaboratively so that home-based online learning can be appropriately synergized. Third, peer support or collaboration is also essential to successful online learning (Mh, 2020; Sikirit, 2020). Such collaboration among teachers will help find solutions to adjusting subject matter to help teachers, and teachers can share ways in which they motivate students and overcome student boredom during instruction by sharing online learning experiences.

Thus, if the School from Home program is to continue successfully, several factors must be considered. First is changing in the national curriculum to ensure flexibility and harmonization with all learning components. Second, technology readiness must be accelerated via easier and more widespread access to the Internet and the provision of Internet networks. Third, teacher training on the use of technology applications should be accelerated (Macià \& García, 2018; Semenova, 2019). Fourth, providing open education resources would reduce the operational costs of online learning (Harsasi, 2015; Kalman, 2017; Management Association, 2015). Fifth, collaboration among teachers, parents, schools should be boosted to improve the process and morale (Borup et al., 2019; Lai, 2017).

\section{Implications}

This study explored the perceptions of primary school teachers of Indonesia's SFH program during the COVID-19 Pandemic. The findings of this study indicate that teachers, as well as learning designers, should design online learning frameworks that consider student backgrounds, especially family economic backgrounds, as well as students' learning experiences and needs in implementing the national curriculum during the COVID-19 Pandemic. This research shows that designing online learning with varied learning strategies in harmony with a more flexible national curriculum, technological readiness, and collaboration is critical to successful online learning. Such flexibility is essential because Indonesia has a vast geographic spread stretching 1,000 miles from north to south and more than 3,100 miles from east to west, with more than 14,000 UN registered islands.

\section{Limitations and Suggestions for Future Research}

This study used a qualitative research design encompassing surveys and interviews to explore perceptions of classroom teachers in primary schools about the impact of SFH during the COVID-19 Pandemic for 3-4 months in 2020. As does all research, this study has limitations. This research was a small representation of elementary school class teachers who teach online throughout Indonesia. For this reason, future research to be more comprehensive and requires quantitative studies or mixed-methods studies. Future research could address the perceptions of students and parents about the implementation of online learning during SFH. The research could 
be expanded to other provinces in Indonesia. Last, the research could examine the development of online learning curriculum models for students of diverse backgrounds

\section{Conclusion}

School from Home during the COVID-19 Pandemic has impacted the educational systems of all countries across the globe significantly. In response to this crisis, countries have applied different rules and methods for dealing with changes in the learning system. Within a few months, national educational systems turned to solutions like online methods (using online applications, $\mathrm{TV}$, radio and offline methods including printed books and modules. Along with these changes, alterations have been necessary for instructional strategies, technological readiness to implement online learning and providing support and motivation to all concerned parties. While the great hope is that the situation soon returns to normal, in the meantime, changes in national curricula must be made to increase flexibility, and technological readiness must be accelerated. Lastly, education must be viewed as collaborative community effort among government, teachers, parents, and schools to increase the efficacy of teaching-and-learning methods that have been adversely affected and ensure that students do not fall behind.

\section{References}

Abdo, M., \& Semela, T. (2010). Teachers of Poor Communities: The Tale of Instructional Media Use in Primary Schools of" Gedeo" Zone, Southern Ethiopia. Australian Journal of Teacher Education, 35(7), 78-92.

Aini, W. N. (2013). Instructional media in teaching English to young learners: A case study in elementary schools in Kuningan. Journal of English and Education, 1(1), 196-205.

Alrefaie, Z., Hassanien, M., \& Al-Hayani, A. (2020). Monitoring Online Learning During COVID19 Pandemic; Suggested Online Learning Portfolio (COVID-19 OLP). MedEdPublish, 9(1). https://doi.org/10.15694/mep.2020.000110.1

Anney, V. N. (2014). Ensuring the quality of the findings of qualitative research: Looking at trustworthiness criteria. Journal of Emerging Trends in Educational Research and Policy Studies (JETERAPS), 5(2), 272-281.

Arsyad, A. (2014). Media Pembelajaran Jakarta: Rajawali Pers.

Bakalar, B. (2018). Book Review: Justice on both sides: Transforming education through restorative justice. American Journal of Qualitative Research, 2(2), 145-149.

Baturay, M. H. (2008). Characteristics of basic instructional design models. Ekev Academic Review, 12(34), 471-482.

Borup, J., Chambers, C. B., \& Stimson, R. (2019). Online Teacher and On-Site Facilitator Perceptions of Parental Engagement at a Supplemental Virtual High School. The International Review of Research in Open and Distributed Learning, 20(2). https://doi.org/10.19173/irrodl.v20i2.4237

Braun, V., \& Clarke, V. (2006). Using thematic analysis in psychology. Qualitative Research in Psychology, 3(2), 77-101.

Cao, Y., Lin, C.-Y., \& Wang, B. (2010). Question and answer search. U.S. Patent Application 12/403,506, filed September 16, 2010.

Centers for Desease Control and Prevention. (2020). Interim Guidance for Administrators of US K-12 Schools and Child Care Programs Plan, Prepare, and Respond to Coronavirus Disease $\quad 2019 \quad$ (COVID-19).

https://www.cdc.gov/coronavirus/2019- 
ncov/community/schools-childcare/guidance-for-

schools.html?CDC_AA_refVal=https\%3A\%2F\%2Fwww.cdc.gov\%2Fcoronavirus\%2F20 19-ncov\%2Fspecific-groups\%2Fguidance-for-schools.html

Conrad, R.-M., \& Donaldson, J. A. (2011). Engaging the online learner: Activities and resources for creative instruction (Vol. 38). John Wiley \& Sons.

Creswell, J. W. (2011). Controversies in mixed methods research. The Sage Handbook of Qualitative Research, 4, 269-284.

Dick, W. (2013). A model for the systematic design of instruction. Instructional Design: International Perspectives I: Volume I: Theory, Research, and Models: Volume Ii: Solving Instructional Design Problems, 361.

Galloway, F. J., \& Jenkins, J. R. (2005). The Adjustment Problems Faced by International Students in the United States: A Comparison of International Students and Administrative Perceptions at Two Private, Religiously Affiliated Universities. NASPA Journal, 42(2). https://doi.org/10.2202/0027-6014.1471

Gurer, C. (2019). Refugee Perspectives on Integration in Germany. American Journal of Qualitative Research, 3(2), 52-70. https://doi.org/10.29333/ajqr/6433

Guo, B., \& Li, H. (2020). Guidance Strategies for Online Teaching during the COVID-19 Epidemic: A Case Study of the Teaching Practice of Xinhui Shangya School in Guangdong, China. SSRN Electronic Journal. https://doi.org/10.2139/ssrn.3565627

Harsasi, M. (2015). THE USE OF OPEN EDUCATIONAL RESOURCES IN ONLINE LEARNING: A Study of Students' Perception. Turkish Online Journal of Distance Education, O(0). https://doi.org/10.17718/tojde.46469

Hennessy, S., Ruthven, K., \& Brindley, S. (2005). Teacher perspectives on integrating ICT into subject teaching: Commitment, constraints, caution, and change. Journal of Curriculum Studies, 37(2), 155-192. https://doi.org/10.1080/0022027032000276961

Hunter, L., \& St Pierre, L. (2016). Online Learning: Report to the Legislature. Washington Office of Superintendent of Public Instruction.

Inoue, Y. (Ed.). (2007). Online Education for Lifelong Learning: IGI Global. https://doi.org/10.4018/978-1-59904-319-7

Kadzera, C. M. (2006). Use of instructional technologies in teacher training colleges in Malawi.

Kalman, Y. M. (2017). Open Educational Resources: Policy, Costs, and Transformation. The International Review of Research in Open and Distributed Learning, 18(3). https://doi.org/10.19173/irrodl.v18i3.3108

Karataş, K., \& Oral, B. (2015). Teachers' Perceptions on Culturally Responsiveness in Education. Journal of Ethnic and Cultural Studies, 2(2), 47. https://doi.org/10.29333/ejecs/39

Kaup, S., Jain, R., Shivalli, S., Pandey, S., \& Kaup, S. (2020). Sustaining academics during COVID-19 pandemic: The role of online teaching-learning. Indian Journal of Ophthalmology, 68(6), 1220. https://doi.org/10.4103/ijo.IJO_1241_20

Khairuddin, A. Z., Abd Razak, A., Idrus, F., \& Ismail, N. A. H. (2019). Challenges of Offering Peace Education among Educational Leaders: A Case Study of Malaysian Public Primary School. American Journal of Qualitative Research, 3(1), 5771. https://doi.org/10.29333/ajqr/5811

Ko, S., \& Rossen, S. (2017). Teaching online: A practical guide. Routledge.

Lemay, D. J., \& Doleck, T. (2020). Online Learning Communities in the COVID-19 Pandemic: Social Learning Network Analysis of Twitter during the Shutdown. International Journal of Learning Analytics and Artificial Intelligence for Education (IJAI), 2(1), 85. https://doi.org/10.3991/ijai.v2i1.15427 
Lincoln, Y. S., Guba, E. G., \& Pilotta, J. J. (1985). Naturalistic inquiry. International Journal of Intercultural Relations, 9(4), 438-439. https://doi.org/10.1016/0147-1767(85)90062-8

Liu, L. (2011). An international graduate student's ESL learning experience beyond the classroom. TESL Canada Journal, 77-92.

Macià, M., \& García, I. (2018). Professional development of teachers acting as bridges in online social networks. Research in Learning Technology, 26(0). https://doi.org/10.25304/rlt.v26.2057

Management Association, I. R. (Ed.). (2015). Open Source Technology: Concepts, Methodologies, Tools, and Applications. IGI Global. https://doi.org/10.4018/978-1-4666-7230-7

Mh, J. (2020). Learning at Home in the Family Environment during the Covid-19 Pandemic [Preprint]. Open Science Framework. https://doi.org/10.31219/osf.io/syv48

Nanjing Normal University, Nanjing 210097, Jiangsu, China, \& Cheng, X. (2020). Challenges of "School's Out, But Class's On" to School Education: Practical Exploration of Chinese Schools during the COVID-19 Pandemic. Science Insights Education Frontiers, 5(2), 501516. https://doi.org/10.15354/sief.20.ar043

Ogbonna, C. G., Ibezim, N. E., \& Obi, C. A. (2019). Synchronous versus asynchronous e-learning in teaching word processing: An experimental approach. South African Journal of Education, 39(2).

Papachristos, D., Arvanitis, K., Vassilakis, K., Kalogiannakis, M., Kikilias, P., \& Zafeiri, E. (2010). An Educational Model for Asynchronous E-Learning. A Case Study in a Higher Technology Education. International Journal of Advanced Corporate Learning (IJAC), 3(1), 32-36.

Patrick, B. C., Hisley, J., \& Kempler, T. (2000). "What's everybody so excited about?": The effects of teacher enthusiasm on student intrinsic motivation and vitality. The Journal of Experimental Education, 68(3), 217-236.

Patton, M. Q. (2014). Qualitative research \& evaluation methods: Integrating theory and practice. Sage publications.

Rachmadtullah, R., Marianus Subandowo, R., Humaira, M. A., Aliyyah, R. R., Samsudin, A., \& Nurtanto, M. (n.d.). Use of Blended Learning with Moodle: Study Effectiveness in Elementary School Teacher Education Students during The COVID-19 pandemic.

Rasmitadila, R., Widyasari, W., Humaira, M. A., Tambunan, A. R. S., Rachmadtullah, R., \& Samsudin, A. (2020). Using Blended Learning Approach (BLA) in Inclusive Education Course: A Study Investigating Teacher Students' Perception. International Journal of Emerging Technologies in Learning (IJET), 15(02), 72-85.

Regulation of Indonesian Goverment No.21, 2020. (2020). Large-scale social restrictions in order to accelerate the handling of Corona Virus Disease 2019 (Covid-19). https://setkab.go.id/inilah-pp-pembatasan-sosial-berskala-besar-untuk-percepatanpenanganan-covid-19/

Richardson, J. W., Hollis, E., Pritchard, M., \& Novosel-Lingat, J. E. M. (2020). Shifting Teaching and Learning in Online Learning Spaces: An Investigation of a Faculty Online Teaching and Learning Initiative. Online Learning, 24(1). https://doi.org/10.24059/olj.v24i1.1629

Ruthven, K., Hennessy, S., \& Brindley, S. (2004). Teacher representations of the successful use of computer-based tools and resources in secondary-school English, mathematics and science. Teaching and Teacher Education, 20(3), 259-275. https://doi.org/10.1016/j.tate.2004.02.002

Semenova, G. (2019). Psychological Readiness To Use Distance Learning Among Teachers Involved In Digitalization. 753-763. https://doi.org/10.15405/epsbs.2019.12.80 
Sikirit, D. (2020). Learning from home during the COVID-19 pandemic. https://www.unicef.org/indonesia/coronavirus/stories/learning-home-during-covid-19pandemic

Strunc, A. (2020). Editorial: Are They Listening? Policymakers and Their Role in Public Education. Research in Educational Policy and Management, 2(1), i-iii. https://doi.org/10.46303/repam.02.01.ed

Sturm, E., \& Quaynor, L. (2020). A Window, Mirror, and Wall: How Educators Use Twitter for Professional Learning. Research in Social Sciences and Technology, 5(1), 22-44. https://doi.org/10.46303/ressat.05.01.2

Tadeu, P., Fernandez Batanero, J., \& Tarman, B. (2019). ICT in a Global World. Research in Social Sciences and Technology, 4(2), i-ii. https://doi.org/10.46303/ressat.04.02.ed

Tarman, B. (2020). Editorial: Reflecting in the shade of pandemic. Research in Social Sciences and Technology, 5(2), i-iv. https://doi.org/10.46303/ressat.05.02.ed

The World Bank. (2020). How countries are using edtech (including online learning, radio, television, texting) to support access to remote learning during the COVID-19 pandemic. https://www.worldbank.org/en/topic/edutech/brief/how-countries-are-using-edtech-tosupport-remote-learning-during-the-covid-19-pandemic

United Nations Educational, Scientific and Cultural Organization. (2020). COVID-19 Impact on Education. https://en.unesco.org/covid19/educationresponse

Vlachopoulos, D. (2020). COVID-19: Threat or Opportunity for Online Education? Higher Learning Research Communications, 10(1). https://doi.org/10.18870/hlrc.v10i1.1179

Watson, E. (2020). \#Education: The Potential Impact of Social Media and Hashtag Ideology on the Classroom. Research in Social Sciences and Technology, 5(2), 40-56. https://doi.org/10.46303/ressat.05.02.3

Whitaker, T., Whitaker, B., \& Lumpa, D. (2013). Motivating \& inspiring teachers: The educational leader's guide for building staff morale. Routledge.

World Health OrganiZation. (2019). Coronavirus disease (COVID-19) advice for the public. https://www.who.int/emergencies/diseases/novel-coronavirus-2019/advice-for-public

Yin, R. K. (2012). Case study methods. In H. Cooper, P. M. Camic, D. L. Long, A. T. Panter, D. Rindskopf, \& K. J. Sher (Eds.), APA handbook of research methods in psychology, Vol 2: Research designs: Quantitative, qualitative, neuropsychological, and biological. (pp. 141155). American Psychological Association. https://doi.org/10.1037/13620-009

\section{Notes on Contributors}

Rasmitadila is a researcher and lecturer of the Elementary School Teacher Education Department of Education Faculty at Djuanda University Indonesia. She has worked in several research projects in the field of elementary teacher education, inclusive education, instructional system, curriculum, and materials development.

Rusi Rusmiati Aliyyah is a researcher and lecturer of the Elementary School Teacher Education Department of Education Faculty at Djuanda University Indonesia. She has worked in several research projects in the field of management of education and teacher education.

Reza Rachmadtullah is a lecturer and researcher at the Department of Elementary School Teacher Education of Education Department Universitas PGRI Adi Buana, Surabaya, Indonesia. His research interest is instructional multimedia, instructional strategies, and inclusive education.

Achmad Samsudin is a lecturer and researcher at the Department of Physics Education, Faculty of Mathematics and Natural Science Education, Universitas Pendidikan Indonesia, 
Bandung, Indonesia. His research interest is physics education, especially in the misconceptions, conceptual change, and conceptual understanding.

Ernawulan Syaodih is a lecturer and researcher at the Department of Early Childhood Education, Universitas Pendidikan Indonesia, Bandung, Indonesia. Her research interest is social skill's student, curriculum, and children development.

Muhammad Nurtanto is a lecturer and researcher at the Department of Mechanical Engineering Education, Faculty of Teaching dan Training Education, Universitas Sultan Ageng Tirtayasa, Banten, Indonesia. His research interest is Media Education, STEM Education, Professional Teaching, Vocational Education, TVET.

Anna Riana Suryanti Tambunan is a researcher and lecturer of education at the State University of Medan Indonesia. She has worked in research projects in the field of language. 